\title{
IRRIGATION DIMENSIONING OF REEL MACHINES WITH WATER DISTRIBUTION SYSTEMS: GUN AND BOOM WITH EMITTERS
}

\section{DIMENSIONAMIENTO DEL RIEGO DE ENROLLADORES CON SISTEMAS DE DISTRIBUCION DEAGUA: CAÑON Y RAMAL CON EMISORES}

\author{
Esequiel Rolando Jiménez Espinosa ${ }^{(1)}$ \\ (1) Agrometeorology Department, Hydrometeorological Service. Ministry of Agriculture of Guyana. \\ Stabroek, Georgetown, Guyana. \\ e-mail: esequieljimenez79@gmail.com
}

\begin{abstract}
The reel machines irrigation technique has expanded in recent years thanks to the technological improvements that have been introduced. Several investigations have been carried out regarding the effectiveness of the irrigation of this equipment with "gun" type water distribution systems, but very few about the "boom with emitters". This includes methodological or calculation procedures for dimensioning irrigation in an agricultural area. Therefore, the objective of this work is to establish a comprehensive methodology for the correct dimensioning of irrigation by reel machines with water distribution systems of the "gun" and "boom with emitters" type. Agronomic design is addressed as a fundamental part, and hydraulic design up to the necessary pressure in the hydrant. The relevant aspects in this procedure are that, formulations are included for the dimensioning of irrigation with water distribution systems of the "boom with emitters" type, and that correct values and criteria are used to support the methodology, because these come from authors and institutions of international prestige.
\end{abstract}

Keywords: reel machines, gun, boom with emitters, water distribution, irrigation dimensioning.

\section{RESUMEN}

La técnica de riego por enrolladores se ha expandido en los últimos años gracias a las mejoras tecnológicas que se le han introducido. Se han realizado varias investigaciones en cuanto a la efectividad del riego de estos equipos con sistemas de distribución de agua del tipo "cañón", pero muy pocas sobre los "ramales con emisores". Esto incluye los procedimientos metodológicos o de cálculo para el dimensionamiento del riego en un área agrícola. Por lo que el objetivo de este trabajo es establecer una metodología integral para el correcto dimensionamiento del riego por enrolladores con sistemas de distribución de agua del tipo “cañón” y "ramal con emisores". Se aborda el diseño agronómico como parte fundamental, y el diseño hidráulico hasta la presión necesaria en el hidrante. Los aspectos relevantes en este procedimiento son que, se incluyen formulaciones para el dimensionamiento del riego con sistemas de distribución de agua del tipo "ramal con emisores", y que se utilizan valores y criterios acertados para soportar la metodología, ya que provienen de autores e instituciones de prestigio internacional.

Palabras clave: enrolladores, cañón, ramal con emisores, distribución de agua, dimensionamiento del riego. 


\section{INTRODUCTION}

According to González (2003), the reel irrigation technique has led to a great expansion of its use in the world. These equipments have evolved over the years, expanding their use in terrain with considerable slopes, in addition to achieving a high use of hydraulic energy, due to new generations of sprinklers and booms with emitters, and also to the design of more efficient turbines (Allen et al ., 2000; Uribe et al., 2001).

On the other hand, Jiménez et al. (2015) stated that in the irrigation with reels machines, there is a boom with emitters modality (ala piovana), for the irrigation of small crops that has the advantage that, during its operation, it requires low working pressure. However, what undermines this sprinkle irrigation technique is the high intensity of application, restricting its use to soils with high infiltration rates. Said author raised another problem where the overlapping percentages established for the design of this equipment with traveling sprinklers are inadequate where there are high wind speeds, as well as prevailing transverse and diagonal wind directions with respect to the movement of the sprinkler.

As in all irrigation techniques, there are methodologies for dimensioning irrigation in traveling irrigation machines (reels machines). For example, NRCS (2005) establishes some considerations for the correct design of traveling sprinklers. Sánchez et al (2015), proposed a methodology for the irrigation management in sugar cane where he establishes a series of formulations associated with traveling irrigation guns. Rolim and Teixeira (2016) propose a software with their methodological support for the design and evaluation of irrigation systems with traveling gun. Tarjuelo (2005), also developed a procedure for irrigation design with this type of water distribution system.

However, the established methodologies do not address specific aspects of reel machines with "boom with emitters" type water distribution systems. Some authors and institutions such as Tarjuelo (2005) and NRCS (2005) only refer to general aspects of these devices.

Based on the foregoing, the goal of this work is to establish a comprehensive methodology for the correct dimensioning of irrigation by reels machines with water distribution systems of the "gun" and "boom with emitters" type.

\section{CALCULATION PROCEDURE}

\section{Agronomic design}

The first step is to obtain information about crop water requirement $(N)$ in its period of greatest demand (in $\mathrm{mm}$ or $\mathrm{L} / \mathrm{m}^{2}$ ). Then the partial net irrigation depth is determined with the following universal formula for the calculation of any irrigation system:

$$
\mathrm{Dn}=10 \cdot \mathrm{bd} \cdot \mathrm{H} \cdot(\mathrm{Fc}-\mathrm{Wp})
$$

where Dn: partial net irrigation depth in $\mathrm{mm}$; bd: bulk density in $\mathrm{g} / \mathrm{cm}^{3} ; \mathrm{H}$ : roots effective depth in $\mathrm{cm}$; Fc: field capacityin $\mathrm{cm}^{3} / \mathrm{cm}^{3}$ and Wp: wilting point in $\mathrm{cm}^{3} / \mathrm{cm}^{3}$

The physical properties of the soils can be obtained from local research data or values estimated by various authors such as Hansen et al. (1980) shown in Table 1. The formulations developed by Saxton et al. (1986) can also be used in the case where local soil texture data are available.

Table 1. Physical properties of soils according to texture.

\begin{tabular}{|c|c|c|c|c|}
\hline Texture & $\begin{array}{c}\text { Porosity } \\
\mathbf{( \% )}\end{array}$ & $\begin{array}{c}\text { Bulk } \\
\text { Density } \\
\left(\mathbf{g} / \mathbf{c m}^{\mathbf{3}}\right)\end{array}$ & $\begin{array}{c}\text { Field } \\
\text { Capacity } \\
\text { (pds) }\end{array}$ & $\begin{array}{c}\text { Wilting } \\
\text { Point } \\
\text { (pds) }\end{array}$ \\
\hline S & 38 & 1.65 & 9 & 4 \\
\hline SL & 43 & 1.5 & 14 & 6 \\
\hline L & 47 & 1.4 & 22 & 10 \\
\hline CL & 49 & 1.33 & 27 & 13 \\
\hline SC & 51 & 1.3 & 31 & 15 \\
\hline C & 53 & 1.25 & 36 & 17 \\
\hline pds- percent dry soil & \multicolumn{3}{|c|}{$\begin{array}{c}\text { CL- Clay Loam } \\
\text { S- Sand } \\
\text { SL- Sandy Clay } \\
\text { C- Clay } \\
\text { L- Loam }\end{array}$} \\
\multicolumn{4}{|c}{} \\
\hline
\end{tabular}

The irrigation frequency is calculated as the ratio between the partial net irrigation depth (Dn) and the crop water requirements $(\mathrm{N})$.

$$
\mathrm{I}_{\mathrm{f}}=\frac{\mathrm{Dn}}{\mathrm{N}}
$$

where $I_{f}$ : irrigation frequency (dimensionless)

Decimal values of the irrigation frequency are generally obtained. But in practice it is convenient to irrigate with days of entire intervals. Therefore, the $I_{f}$ value is approached to an integer value and equation (2) is solved for: 


$$
\mathrm{Dn}_{\mathrm{a}}=\mathrm{N} \cdot \mathrm{I}_{\mathrm{fe}}
$$

where $\mathrm{Dn}_{\mathrm{a}}$ : adjusted partial net irrigation depth in $\mathrm{mm}$ and $\mathrm{I}_{\mathrm{fe}}$ : irrigation frequency (entire value)

Then the gross irrigation depth is calculated:

$$
\mathrm{Db}=\frac{\mathrm{Dn}_{\mathrm{a}}}{\mathrm{Ea}}
$$

where $\mathrm{Db}$ : gross irrigation depth in $\mathrm{mm}$ and $\mathrm{Ea}$ : application efficiency

There is an extensive specialized literature where application efficiency values for this irrigation technique are provided. The following information is shown below (Table 2).

Table 2. Application efficiency values for traveling irrigation

\begin{tabular}{|c|c|c|}
\hline \multicolumn{3}{|c|}{ machines. } \\
\hline $\begin{array}{c}\text { Denomination } \\
\text { Traveling sprinklers (gun } \\
\text { type or boom) }\end{array}$ & $55-65$ & $\begin{array}{c}\text { NRCS } \\
(2005)\end{array}$ \\
\hline $\begin{array}{c}\text { Travelling sprinkler (gun } \\
\text { type) }\end{array}$ & $65-77$ & Keller (1990) \\
\hline $\begin{array}{c}\text { Gun (drawn by reel or } \\
\text { cable) }\end{array}$ & $55-70$ & $\begin{array}{c}\text { Santos et al } \\
(2010)\end{array}$ \\
\hline \multicolumn{2}{|c}{} \\
\hline \multicolumn{2}{|c}{}
\end{tabular}

If there is information from field evaluations, the equation proposed by Walker (1979), quoted by USDA-SCS (1993), can be used.

$$
\begin{aligned}
& \mathrm{Ea}=\left[1-(1.25-0.0125 \cdot \mathrm{CU})\left(3.634-1.123 \cdot \mathrm{A}_{\mathrm{u}}{ }^{0.3}+\right.\right. \\
& \left.\left.+0.003 \cdot \mathrm{A}_{\mathrm{u}}^{1.233}\right)\right]
\end{aligned}
$$

where Ea: application efficiency $(\%) ; \mathrm{A}_{\mathrm{u}}$ : fraction of the field that is deficitly irrigated and CU: coefficient of uniformity.

To determine the flow of the irrigation system the formula is used (Tarjuelo, 2005):

$$
\mathrm{Q}=\frac{(3.6 \cdot \mathrm{N} \cdot \mathrm{A})}{(\mathrm{Ea} \cdot \mathrm{Trd})}
$$

where Q: flow of irrigation system in L/s; A: area to irrigate in ha and Trd; hours of system operation in h/day.

Therefore, the water supply rate is calculated as:

$$
\mathrm{q}=\frac{\mathrm{Q}}{\mathrm{A}}
$$

where q: water supply rate in $\mathrm{L} /$ (s.ha).

Application rate is an important design parameter, because the infiltration capacity of the soil must be ensured. Therefore, the selection of the sprinkler is correct when the application rate of the rain is below the infiltration rate. In the case of irrigation guns, it is determined as follows:

$$
\mathrm{I}=\frac{\mathrm{Q}_{\mathrm{E}}}{\mathrm{A}_{\mathrm{S}}}
$$

where I: application rate in $\mathrm{mm} / \mathrm{h} ; \mathrm{Q}_{\mathrm{E}}$ : flow of reel machine in $\mathrm{L} / \mathrm{h}$ and $\mathrm{A}_{\mathrm{S}}$ : circular sector area in $\mathrm{m}^{2}$.

$$
\mathrm{A}_{\mathrm{S}}=\pi \cdot\left(0.9 \cdot \mathrm{R}_{\mathrm{c}}\right)^{2} \cdot \frac{\alpha}{360}
$$

where $\alpha$ : gun irrigation angle in degrees and $\mathrm{R}_{\mathrm{c}}$ : gun irrigation radius in $\mathrm{m}$

Application rate in boom with emitters is high and its use is limited to soils with a higher infiltration rate. Tarjuelo (2005), states that these water distribution systems must be well dimensioned, otherwise the irrigation depth would have to be applied on more than one route and would make the operation more expensive. On the other hand, Jiménez et al (2015), obtained considerably high application rates values and proposed that booms be developed with emitters of greater wetting width. In this case it is determined as:

$$
I=\frac{Q_{E}}{\left(A_{m} \cdot F_{m}\right)}
$$

where $A_{m}$ : wet width of emitters in $m$ and $F_{m}$ : wet width by the boom with emitters in $\mathrm{m}$.

The space between irrigation settings for the guns is calculated:

$\mathrm{E}=2 \cdot \mathrm{R}_{\mathrm{c}} \cdot \frac{\mathrm{P}_{\mathrm{DM}}}{100}$

where E: space between irrigation settings in $\mathrm{m}$ and $\mathrm{P}_{\mathrm{DM}}$ : wet diameter percent. 
Table 3 shows the spacing values in percent of the wet diameter for jet path angles of $23^{\circ}$ to $25^{\circ}$.

Table 3. Recommended spacing between strips according to wind speed. (Keller and Bliesner, 1990)

\begin{tabular}{|c|c|}
\hline $\begin{array}{c}\text { Wind speed interval } \\
\text { (km/h) }\end{array}$ & $\begin{array}{c}\text { Spacing as \% of the wet } \\
\text { diameter }\end{array}$ \\
\hline 0 to 3.5 & 90 \\
\hline 3.5 to 8 & 80 to 85 \\
\hline 8 to 16 & 70 to 75 \\
\hline$>16$ & 60 to 65 \\
\hline
\end{tabular}

About booms with emitters it is different because a rain curtain is generated. Therefore, the equation is as follows:

$$
\mathrm{E}=\mathrm{L}_{\mathrm{A}}
$$

where $\mathrm{L}_{\mathrm{A}}$ : boom length in $\mathrm{m}$.

However, there are booms with sprinklers, where the last emitters on both sides have a considerable wetting radius. It must be considerate:

$$
\mathrm{E}=\mathrm{L}_{\mathrm{A}}+\left(2 \cdot \mathrm{R}_{\mathrm{DE}} \cdot \frac{\mathrm{P}_{\mathrm{DME}}}{100}\right)
$$

where $\mathrm{P}_{\mathrm{DME}}$ : wet diameter percent of the end sprinklers of the boom; $\mathrm{L}_{\mathrm{A}}$ : boom length in $\mathrm{m}$ and $\mathrm{R}_{\mathrm{DE}}$ : radius irrigation of the emitters of both tips in $\mathrm{m}$.

$$
\mathrm{R}_{\mathrm{DE}}=\frac{\left(\mathrm{F}_{\mathrm{m}}-\mathrm{L}_{\mathrm{A}}\right)}{2}
$$

Table 3 can be used to define the $P_{D M E}$ value, and the values of $F_{m}$ and $L_{A}$ are obtained from the supplier's catalogs.

To define the number of strips to irrigate, the layout defined in the project is analyzed and the lengths of the straight sections of the pipe with hydrants are added to apply the following formula:

$$
\mathrm{B}=\frac{\mathrm{Lc}}{\mathrm{E}}
$$

where $B$ : number of strips to irrigate and $L_{c}$ : length of the pipe with hydrants in $\mathrm{m}$.

It also frequently happens that a decimal value of the number of strips to be irrigated is obtained. In this case, it approaches an integer value and the space between irrigation settings is determined again, obtaining:

$$
\mathrm{E}_{\mathrm{A}}=\frac{\mathrm{Lc}}{\mathrm{B}_{\mathrm{R}}}
$$

where $\mathrm{E}_{\mathrm{A}}$ : adjusted space between irrigation settings, in $m$ and $B_{R}$ : number of strips to irrigate approximate to integer value.

The retraction speed of both the gun and the boom with emitters is determined by the following expression:

$$
\mathrm{V}=\frac{\mathrm{Q}_{\mathrm{E}}}{\mathrm{Db} \cdot \mathrm{E}_{\mathrm{A}}}
$$

where V: retraction speed in $\mathrm{m} / \mathrm{h}$.

Equations 18, 19 and 20 are applicable only to traveling gun irrigation:

$$
\mathrm{D}_{\mathrm{i}}=\frac{2}{3} \cdot \mathrm{R}_{\mathrm{c}}
$$

where $D_{i}$ : distance to the edge of the area to start irrigation, in $\mathrm{m}$.

$$
\mathrm{T}_{\mathrm{i}}=\frac{2}{3} \cdot \frac{\alpha}{360} \cdot \frac{\mathrm{R}_{\mathrm{c}}}{V}
$$

where $T_{i}$ : gun irrigation time without moving to the end of the strip, in min.

$\mathrm{T}_{\mathrm{f}}=\frac{2}{3} \cdot\left(1-\frac{\alpha}{360}\right) \cdot \frac{\mathrm{R}_{\mathrm{c}}}{V}$

where $\mathrm{T}_{\mathrm{f}}$ : gun irrigation time without moving at the beginning of the strip, in min.

To determine the time it takes for the reel machine to irrigate the strip, if the area has regular dimensions, it is determined by the following expression:

$$
\mathrm{T}_{\mathrm{RB}}=\frac{\mathrm{L}_{\mathrm{B}}}{\mathrm{V}}
$$

where $\mathrm{T}_{\mathrm{RB}}$ : time it takes for the reel machine to irrigate the strip, in $\mathrm{h}$ and $\mathrm{L}_{\mathrm{B}}$ : strip length in $\mathrm{m}$. 
In the case of an irregular area, the lengths of all the strips are added together and divided by the number of strips in the area to obtain $L_{B P}$, obtaining:

$\mathrm{T}_{\mathrm{RB}}=\frac{\mathrm{L}_{\mathrm{BP}}}{\mathrm{V}}$

where $\mathrm{L}_{\mathrm{BP}}$ : average length of the strips in $\mathrm{m}$.

So the number of strips to irrigate in a day would be:

$$
\mathrm{N}_{\mathrm{B}}=\frac{\mathrm{T}_{\mathrm{rd}}}{\mathrm{T}_{\mathrm{RB}}+\mathrm{T}_{\mathrm{c}}}
$$

where $\mathrm{N}_{\mathrm{B}}$ : number of strip to irrigate in a day and $\mathrm{T}_{\mathrm{c}}$ : change time between irrigation settings in $h$.

If it is considered that the reel machine must make the complete journey in the strip, the value of $N_{B}$ must be an almost integer or integer number, otherwise the selection of the irrigation equipment must be proceeded to achieve this purpose. But if the reel machines can stay in the field without finishing its journey in the strip, the calculations continue.

To obtain the necessary flow at the pumping station, proceed with the following formulations:

$$
\mathrm{A}_{\mathrm{EI}}=\mathrm{V} \cdot \mathrm{T}_{\mathrm{rd}} \mathrm{E}_{\mathrm{A}} \cdot \mathrm{Ir}_{\mathrm{e}}
$$

where $A_{E I}$ : area irrigated by the reel machine in the irrigation frequency in ha.

$$
\mathrm{C}_{\mathrm{E}}=\frac{\mathrm{A}}{\mathrm{A}_{\mathrm{EI}}}
$$

where $\mathrm{C}_{\mathrm{E}}$ : number of reel machines in the area

$$
\mathrm{Q}_{\mathrm{EB}}=\mathrm{Q}_{\mathrm{E}} \cdot \mathrm{C}_{\mathrm{E}}
$$

where $\mathrm{Q}_{\mathrm{EB}}$ : necessary flow at the pumping station in $\mathrm{L} / \mathrm{s}$.

Generally the $Q_{E B}$ value differs from the $Q$ value due to the adjustments that are made in the calculation process. Therefore, the $Q_{E B}$ value is the one that will be used for the hydraulic design of the network.

\section{Hydraulic Design}

To determine the necessary pressure in hydrant output, suppliers offer technical, hydraulic and operational characteristics of their equipment, which facilitate the design process of the irrigation system. However, the necessary parameters in the hydraulic calculation according to Tarjuelo (2005) are provided below.

$\mathrm{P}_{\mathrm{E}}=\mathrm{P}_{\mathrm{e}}+\Delta \mathrm{h}+\mathrm{h}_{\mathrm{m}}+\mathrm{h}_{\mathrm{e}}+\mathrm{h}_{\mathrm{t}}+\mathrm{h}_{\mathrm{s}}$

where $\mathrm{P}_{\mathrm{e}}$ : pressure in the gun or boom with emitters in m.c.a.; $\Delta \mathrm{h}$ : difference in terrain altitude in the direction of the hose in $\mathrm{m}$ (obtained from topographic information) and $\mathrm{h}_{\mathrm{m}}$ : pressure loss in the hose in m.c.a.

$$
\mathrm{h}_{\mathrm{m}}=\left(10.64+\mathrm{C}^{-1.85}+\mathrm{D}^{-4.87}+\mathrm{Q}_{\mathrm{E}}^{1.85}\right) \cdot \mathrm{L}_{\mathrm{m}}
$$

$\mathrm{L}_{\mathrm{m}}$ : hose length in $\mathrm{m}$; $\mathrm{C}$ : material coefficient; $\mathrm{D}$ : diameter inside the hose in $\mathrm{m}$; $\mathrm{Q}_{\mathrm{E}}$ : flow of reel machine in $\mathrm{m}^{3} / \mathrm{s} ; \mathrm{h}_{\mathrm{e}}$ : height of gun or boom with emitters in $\mathrm{m}$; $\mathrm{h}_{\mathrm{t}}$ : pressure loss inside turbine in m.c.a. and $h_{s}$ : pressure losses in other components in m.c.a.

\section{CONCLUSIONS}

The calculation procedure for irrigation systems with traveling guns and traveling booms with emitters has been established, the latter being the most relevant water distribution system because there is little information regarding formulations for its dimensioning in agricultural areas.

Reliable criteria and indicator values were shown to support this methodology, because this information comes from internationally recognized authors and institutions.

\section{REFERENCES}

Allen, R. G.; Keller, J. and Martin, D. (2000). Center pivot system design. The irrigation association. VA, USA. 300 p. Recuperado de http://www.irrigation.org

González, P. (2003). Avances del riego en el cultivo de la papa en Cuba: Las máquinas de pivote central. Revista Ciencias Técnicas Agropecuarias, 12 (4): 39-43.

Hansen V. E., Israelson O.W. and Stringham G. E. (1980). Irrigation: Principles and Practices. Fourth Edition. New York, USA, Chichester: Wiley.

Jiménez E. R.; Montero L. and Zanette J. (2015). Evaluación de la calidad de riego de máquinas 
móviles (enrolladores). Revista Ingeniería Agrícola, 5(3): 29-34.

Keller J. and Bliesner R. D. (1990). Sprinkle and Tickle Irrigation. New York, NY, USA, Van Nostrand Reinhold.

National Resources Conservation Service (NRCS) (2005). Irrigation System Design (chapter 6), 210-viNEH 652, IG Amend. NJ1. United State Department of Agriculture (USDA). Recuperado de www.nrcs.usda.gov/Internet/FSE_DOCUMENTS/nr cs141p2_017641.pdf

Rolim J. and Teixeira J. L. (2016). The design and evaluation of travelling gun irrigation systems: Enrolador Software. Engenharia Agrícola, 36(5): 917-927. doi: http://dx.doi.org/10.1590/18094430-Eng.Agric.v36n5p917-927/2016.

Sánchez, J. A.; Fernández, Y.; Martínez , M.; Bonet, C.; Hernández, M. A.; Noy, A. (2015). Régimen de riego de explotación con la técnica por enrolladores, en el cultivo de la caña de azúcar (Saccharumofficinarum L.). Agrisost, 22(1): 9-23.

Santos L., de Juan J. A., Picornell M. R. and Tarjuelo J. M. (2010). El Riego y sus Tecnologías. Centro Regional de Estudios del Agua. Universidad de Castilla-La Mancha Campus universitario s/n 02071 Albacete. España. ISBN: 13:978-84-692-9979-1.

Saxton K. E., Rawls W. J., Romberger J.S. and Papendick R. I. (1986) Estimating Generalized Soilwater Characteristics from Texture. Soil Science Society of America Journal. 50(4): 1031-1036.
Soil Conservation Service. (1993). Irrigation Water Requirements (chapter 2). National Engineering Handbook (part 623). United States Department of Agriculture. (210-vi-NEH, September 1993) 2-1.

Tarjuelo, J.M. (2005). El riego por aspersión y su tecnología. Madrid, Barcelona, México.Ed. Ediciones Mundi Prensa, $3^{\text {ra }}$ edición, ISBN: 848476-225-4.

Uribe, H. C.; Lagos, L. O. and Holzaphel, E. (2001). Pivote Central. Comisión Nacional de Riego, Corporación de Fomento de la Producción. Chile. Recuperado de http://www.cnr.gob.cl.

\section{Tipo de Publicación: NOTA TECNICA.}

\section{Trabajo recibido el 30/08/2020 y aprobado para su publicación el 06/11/2020.}

\section{COMO CITAR}

Jiménez Espinosa, E. R. (2020). Irrigation dimensioning of reel machines with water distribution systems: gun and boom with emitters. Cuadernos del CURIHAM. 26: 49-54. DOI: https://doi.org/10.35305/curiham.v26i0.152

Este es un artículo de acceso abierto bajo licencia: Creative Commons Atribución - No Comercial Compartir Igual 4.0 Internacional (CC BY-NC-SA 4.0) (https://creativecommons.org/licenses/by-ncsa/4.0/deed.es) 